http://dx.doi.org/10.18778/0860-6587.22.26

Edyta Patuszyńska

\title{
Anna Trębska-Kerntopf, Aforyzm w nauczaniu języka polskiego jako obcego, Wydawnictwo UMCS, Lublin 2015, ss. 465
}

Monografia Anny Trębskiej-Kerntopf pt. Aforyzm w nauczaniu języka polskiego jako obcego łączy aspekt językoznawczy - ze względu na opis aforyzmu jako małej formy literackiej - z aspektem glottodydaktycznym, ponieważ rozważa przypadki zastosowania wybranego gatunku w dydaktyce języka polskiego jako obcego. Pomimo tego, że praca dotyczy jednego typu tekstu, Autorka dość szeroko kreśli tło badań, omawiając metody nauczania, poziomy biegłości i techniki rozwijania sprawności językowych. Tak różnorodne treści z pewnością poszerzają krąg potencjalnych odbiorców książki, która jest zgodna z najnowszymi osiągnięciami metodyki.

W glottodydaktyce w ostatnich latach coraz częściej pisze się o konieczności nabywania nie tylko kompetencji komunikacyjnej, ale i kulturowej, a zwłaszcza międzykulturowej (interkulturowej). Aby osiągnąć ten cel, wprowadza się różne teksty kultury, które mogą być użyte w funkcji autentycznego tekstu dydaktycznego. Dotyczy to również aforyzmów. Dobrze się stało, że zajęła się tym problemem Anna Trębska-Kerntopf, dydaktyk o dużym doświadczeniu w nauczaniu cudzoziemców języka polskiego. Książka jest efektem wieloletnich badań nad aforyzmami i stanowi ukoronowanie wcześniej publikowanych artykułów na temat zastosowania aforyzmów w nauczaniu języka polskiego jako obcego. Wysoki poziom metodyczny książka zawdzięcza niewątpliwie możliwości praktycznego testowania rozwiązań wprowadzanych na lekcjach języka polskiego z cudzoziemcami w Centrum Języka i Kultury Polskiej dla Polonii i Cudzoziemców UMCS.

Podstawa materiałowa pracy jest bardzo bogata, liczy ponad 60 tys. aforyzmów z 31 źródeł, które Autorka wymienia we wstępie. Jest to więc materiał obszerny, pozwalający na sformułowanie miarodajnych wniosków. Wprowadzone skróty dzieł umożliwiają każdorazową lokalizację wyselekcjonowanych przykładów, co stanowi o wartości dokumentacyjnej pracy i świadczy o rzetelności naukowej Autorki.

Połączenie ujęcia językoznawczego i dydaktycznego znalazło odzwierciedlenie w dwudzielnym charakterze książki, która składa się z części: Aforyzm jako miniatura literacka i Aforyzm w praktyce glottodydaktycznej. W części pierwszej, składającej się z dwu rozdziałów, czytelnik otrzymuje rzetelnie opracowany rozdział teoretyczny dotyczący aforyzmu, jego wyznaczników gatunkowych, specyfiki budowy, historii gatunku oraz gry jako wszechstronnego narzędzia analizy tekstów. Anna Trębska-Kerntopf przedstawia cechy aforyzmu w ujęciu polskich i rosyjskich uczonych, następnie zestawia je z dziesięcioma definicjami wybranymi z różnych słowników i encyklopedii. Analizuje również, w jaki sposób sami autorzy aforyzmów określają ich charakter. Wymienione czynności poprzez ich zestawienie pozwalają Autorce wyłonić cechy konstytutywne dla tego gatunku i następnie zaproponować własną definicję, którą warto przytoczyć: , Aforyzm jest to krótkie, zwięzłe i przeważnie błyskotliwe sformułowane zdanie wyrażające myśl filozoficzną lub moralną. Często oparte na paradoksie” (s. 52). W rozdziale drugim części pierwszej Anna Trębska -Kerntopf przybliża narzędzie analityczne, jakim jest gra i wykorzystuje je do opisu najróżniejszych

${ }^{1}$ edyta.paluszynska@gmail.com, Katedra Lingwistyki Stosowanej i Kulturowej, Wydział Filologiczny, Uniwersytet Łódzki,90-236 Łódź, ul. Pomorska 171/173. 
sposobów organizacji struktury i semantyki aforyzmów. Wybór narzędzia należy uznać za trafny, gdyż pozwala ono na wielowymiarowy i wieloaspektowy ogląd bardzo zróżnicowanych realizacji wybranego gatunku. Autorka wyodrębnia gry oparte na aktywnym wykorzystaniu frazeologizmów, gry inicjalnymi komponentami ramy tekstowej, gry stylizacyjne, gry językowe wykorzystujące relacje w polu znaczeniowym (w tym gry synonimami, antonimami, polisemami i homonimami), gry formalno-semantyczne, gry semantyczno-składniowe, gry wybranymi kategoriami tematycznymi, gry wybranymi wartościami, gry aluzjami literackimi i gry wyróżnieniami typograficznymi. Podział aforyzmów ze względu na rodzaj gry nie jest rozłączny, ale raczej uwzględnia dominantę semantyczną. Ciekawie prezentują się aforyzmy, mające postać definicji, komparycji, dyrektywy, pytania retorycznego i pozorowanego dialogu. Najliczniejsze (ponad 600) mają kształt definicji, na którą składają się trzy elementy: definiendum, definiens i spójka łącząca oba człony. Ze względu na postać spójki definicyjnej Autorka wydzieliła aż 17 rodzajów definicji. W definicjach aforystycznych często pojawia się metafora i w konsekwencji węzeł semantyczny. Aforyzmy o strukturze porównania (90 poświadczeń) omawiane są według koniunktora. Do najczęstszych należy: Im x.......tym y. Aforyzmy mogą mieć również formę dyrektyw, pouczeń, apeli, ostrzeżeń, oraz rzadziej, pytań retorycznych lub dialogu: pytanie - odpowiedź. W rozprawie zwrócono też uwagę na incipity aforyzmów, takie jak: człowiek, ludzie, wszyscy, każdy, niejeden, niejedni, niektórzy, kto. Są to incipity wskazujące na ważną cechę gatunku, jaką jest filozoficzne, moralistyczne uogólnienie. W sumie rozdział dotyczący rodzajów gier przynosi ciekawe i funkcjonalne narzędzie analizy bardzo różnorodnych zjawisk językowych, które może zostać wykorzystane nie tylko w odniesieniu do aforyzmów. Narzędzie, jakim jest szeroko rozumiana gra, gromadzi we wspólnym polu obserwacji zjawiska tak różne jak: typy leksemów i relacji między nimi, stylizacje, struktury semantyczno-składniowe, kategorie tematyczne, kształt graficzny. Dzięki wypracowaniu tak wszechstronnego narzędzia, praca Anny Trębskiej-Kerntopf zyskuje znaczną wartość metodologiczną.

Pomimo tego, że Autorka przewiduje zastosowanie aforyzmów głównie w glottodydaktyce, można śmiało rozszerzyć krąg odbiorców Jej książki na polonistyczne środowisko akademickie. Przykłady aforyzmów wykorzystujących relacje w polu znaczeniowym, takie jak synonimia, antonimia, polisemia, homonimia mogą wzbogacić zajęcia z leksykologii, a aforyzmy z nazwami własnymi - zajęcia z onomastyki.

W części drugiej Autorka koncentruje się na roli aforyzmu w dydaktyce języka polskiego jako obcego. Rozważania szczegółowe zostały poprzedzone obszernym rozdziałem teoretycznym zawierającym wybór nowoczesnych metod nauczania i rozdziałem traktującym o tekście autentycznym w glottodydaktyce. W rozdziale trzecim części drugiej Autorka, nawiązując do polskiej wersji Europejskiego systemu opisu kształcenia językowego słusznie stwierdza, że w przypadku sześciu poziomów biegłości językowej aforyzmy należy wprowadzać na poziomie C1 (poziom efektywnej biegłości językowej), szczególnie jednak na poziomie C2 (poziom perfekcyjnego opanowania języka). Pokazuje, jaką kompetencję w zakresie pięciu sprawności trzeba posiadać na poziomie C1 i C2 oraz wyjaśnia, dlaczego aforyzm jako tekst autentyczny dobrze służy kształceniu tych sprawności. Skupia się przy tym na sprawnościach receptywnych (rozumienie ze słuchu i rozumienie tekstu czytanego) oraz na sprawnościach produktywnych (mówieniu i pisaniu). Na stronach 274, 283, 298, 313, i kolejnych, nie tylko je przedstawia, opisuje techniki i strategie, ale wprowadza stały 
element opisu, jakim są propozycje dydaktyczne. Umieszcza w nich szereg ćwiczeń rozwijających poszczególne sprawności. Aforyzmom towarzyszą inne teksty kultury, np. piosenki, wiersze, teksty prasowe, filmy, słowniki, encyklopedie. Autorka podaje całe scenariusze lekcji z wykorzystaniem aforyzmów, np. Być kobietq ... w XXI wieku, Bukiet prawdę ci powie..., jeśli znasz mowę kwiatów, Pieniądz rządzi światem i inne. W tej części książki na podkreślenie zasługuje powoływanie się nie tylko na bogatą literaturę metodyczną, dotyczącą poszczególnych sprawności, ale i językoznawczą, związaną z tematyką scenariuszy lekcyjnych.

Sporo miejsca (s. 320-341) poświęca Autorka na przedstawienie możliwości zastosowania aforyzmów w rozwijaniu sprawności gramatycznej i leksykalnej, gdyż, jak słusznie zauważa, ze względu na ekspresywność aforyzmy nadają się do wprowadzania nowej leksyki i konstrukcji składniowych. Pojawiają się w nich synonimy, antonimy, polisemy i homonimy, związki frazeologiczne, nazwy własne, aluzje literackie, odwrócenia paralelne i paradoksy. Jak widać, katalog wyodrębnionych i omówionych zjawisk językowych jest bardzo bogaty.

Od strony formalnej monografia Anny Trębskiej-Kerntopf wyróżnia się przejrzystością i wyjątkowym uporządkowaniem wywodu. W każdym rozdziale i podrozdziale czytelnik znajduje najpierw prezentację interesujących Autorkę problemów, następnie ich omówienie teoretyczne, ustosunkowanie się do różnych postaw badawczych i przyjęcie własnej, dalej następuje analiza materiału poprzedzona informacją, w jaki sposób zostanie dokonana. Po każdej zwartej części są propozycje dydaktyczne, w których znajdują się ciekawe przykłady ćwiczeń i scenariuszy lekcji języka polskiego z wykorzystaniem aforyzmów.

Recenzowana monografia to wartościowe studium językoznawcze w zakresie badań nad aforyzmem. Atutem pracy jest jej dokumentacyjny charakter, gdyż Autorka gromadzi w jednym dziele utwory 340 aforystów. Część metodologiczna, a zwłaszcza wykorzystanie pojęcia gry, może stanowić wzór uporządkowania niezwykle różnorodnych cech jednego gatunku, wykraczających poza leksykologię i stylistykę. Dwuplanowość rozprawy wzbogaca ją o aspekt glottodydaktyczny. Jest to jedna z pierwszych prac łączących te dwa elementy. Pokazuje, jak od strony metodycznej można wykorzystać badania teoretyczne nad aforyzmami w praktyce pedagogicznej. Książka Anny Trębskiej-Kerntopf wnosi istotne wzbogacenie warsztatu nauczyciela języka polskiego jako obcego i jest dowodem na żywość glottodydaktyki jako dziedziny badań. 